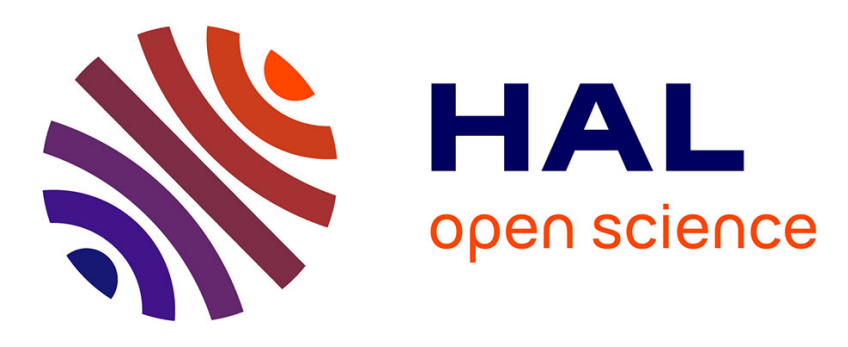

\title{
Water-soluble nickel-bis(dithiolene) complexes as photothermal agents.
}

Kenny Mebrouk, Florian Chotard, Catherine Le Goff-Gaillard, Yannick Arlot-Bonnemains, Marc Fourmigué, Franck Camerel

\section{To cite this version:}

Kenny Mebrouk, Florian Chotard, Catherine Le Goff-Gaillard, Yannick Arlot-Bonnemains, Marc Fourmigué, et al.. Water-soluble nickel-bis(dithiolene) complexes as photothermal agents.. Chemical Communications, 2015, 51 (25), pp.5268-5270. 10.1039/C4CC08231A . hal-01114389

HAL Id: hal-01114389

https://hal-univ-rennes1.archives-ouvertes.fr/hal-01114389

Submitted on 3 Jun 2015

HAL is a multi-disciplinary open access archive for the deposit and dissemination of scientific research documents, whether they are published or not. The documents may come from teaching and research institutions in France or abroad, or from public or private research centers.
L'archive ouverte pluridisciplinaire HAL, est destinée au dépôt et à la diffusion de documents scientifiques de niveau recherche, publiés ou non, émanant des établissements d'enseignement et de recherche français ou étrangers, des laboratoires publics ou privés. 


\section{Water-soluble nickel-bis(dithiolene) complexes as photothermal agents}

Kenny Mebrouk, ${ }^{a}$ Florian Chotard,${ }^{a}$ Catherine Le Goff-Gaillard, ${ }^{b}$ Yannick Arlot-Bonnemains, ${ }^{b}$ Marc Fourmigué $^{a}$ and Franck Camerel ${ }^{a, *}$

${ }^{a}$ Institut des Sciences Chimiques de Rennes (ISCR), UMR-CNRS 6226, Université de Rennes 1, Campus de Beaulieu, 35042 Rennes, France.

${ }^{b}$ Institut de Génétique et développement de Rennes (IGDR), UMR-CNRS 6290 - Université Rennes

\section{The remarkable photothermal properties of pegylated nickel-bis(dithiolene) complexes in water can induce cell death under laser irradiation in the near infrared (NIR) region.}

Photothermal therapy (PTT) is a minimally invasive and harmless therapeutic methodology which employs hyperthermia generated by photothermal agents from laser energy to kill malignant cells. Such a PPT prefers near-infrared (NIR, $\lambda=700-1100 \mathrm{~nm}$ ) radiation with the typical tissue penetration of several centimeters in biological tissues ${ }^{1}$ and has attracted much attention in recent years as a promising alternative or supplement to traditional cancer therapies. Numerous photothermal agents with strong absorbance of NIR laser have been extensively explored to increase the photothermal conversion efficiency and correspondingly, enhance the thermal lethality in tumors. Currently, four families of photothermal agents have been extensively developed, resulting in great contributions to PTT therapy. First, organic compounds such as indocyanine green (ICG) dye and polyaniline nanoparticles, ${ }^{2}$ suffer from limitations such as photobleaching and/or unsatisfactory photothermal conversion efficiency. Besides, carbon-based materials, including carbon nanotubes (CNTs) and graphene, have relatively low absorption coefficient in the NIR region. ${ }^{3}$ The third family consists in metal (particularly gold) nanostructures (supramolecularly assembled 
nanoparticles, nanorods, nanoshells, hollow nanospheres, nanocages, nanocrosses, and nanostars). ${ }^{4}$ These noble metal-based nanostructures exhibit intense NIR photoabsorption and are the most studied photothermal agents, but the intense NIR absorption of these materials is attributed to the surface plasmon resonance (SPR), and their maximum absorption is therefore related to the dielectric constant of the surrounding matrix, leading to a difference of the maximum absorption between in vitro and in vivo. These gold nanomaterials also suffer from relatively low thermal stability during prolonged laser irradiation. The last type is found in copper chalcogenide semiconductors, including $\mathrm{CuS}^{5}$ and $\mathrm{Cu}_{2-x} \mathrm{Se}^{6}$ nanoparticles, but the main limitation of these compounds is their unsatisfactory photothermal conversion efficiency. To meet the severe requirements of future PTA therapy, it is necessary to search for more stable and biocompatible agents displaying high photothermal conversion efficiency in the NIR region.

Nickel-bis(dithiolene) are strong near-IR absorbers with high thermal- and photo-stability (Figure 1). In their neutral state, they display high absorption coefficients (around $30000 \mathrm{M}^{-1} . \mathrm{cm}^{-1}$ ) in organic solvents in a wide range of NIR absorption maxima that are tunable from $600 \mathrm{~nm}$ to $1200 \mathrm{~nm}$ depending on the dithiolene substituents. Furthermore, these complexes are non-luminescent, implying that all the absorbed energy is released in the environment as heat. This peculiar feature has found applications for photothermal laser printing on thin films. ${ }^{7}$ Recently, it has also been demonstrated that the photothermal properties of metallogelators built around nickel-bis(dithiolene) cores can efficiently be used to control the degelation of robust organogels. ${ }^{8}$ Thus, properly functionalized nickel-bis(dithiolene) could be good candidates as photothermal therapeutic agents under near-IR laser irradiation, if they were water-soluble and biocompatible.

In the present work, we report the design and the synthesis of pegylated nickel-bis(dithiolene) complexes displaying photothermal activities in water and their in vitro ability to act as photothermal agents on human renal carcinoma cells. 
Three pegylated nickel-bis(dithiloene) derivatives were considered, depending on the nature of the dithiolate ligand and the number of polyethylene glycol chains (Figure 1). Polyethylene chains have been selected for their good solubility in water and their biocompatibility. ${ }^{9}$ Preparation of complex $\mathbf{1}$ was achieved by treatment of the corresponding pegylated 1,3-dithiole-2-thione derivative with sodium methoxide, followed by addition of a solution of nickel(II) chloride hexahydrate. The bis(oligo(ethyleneoxide)) substituted 1,3-dithiole-2-thione precursor was obtained by direct alkylation of the bis(2-thioxo-1,3-dithiole-4,5-dithio)-zincate salt $\left[\mathrm{Zn}(\mathrm{dmit})_{2}\right]^{2-}$ with 2-methoxy(2-ethoxy(2ethoxyethyl)) $p$-toluenesulfonate in refluxing acetonitrile. For the preparation of complexes $\mathbf{2}$ and $\mathbf{3}, 4,4$ 'dihydroxybenzil and 3,3',4,4'-tetrahydroxybenzil were first alkylated with 2-methoxy(2-ethoxy(2ethoxyethyl)) $p$-toluenesulfonate in refluxing DMF in presence of $\mathrm{K}_{2} \mathrm{CO}_{3}$. The pegylated benzil derivatives were then sulfurated with $\mathrm{P}_{4} \mathrm{~S}_{10}$ in dimethylimidazolidinone (DMI) before addition of an aqueous solution of $\mathrm{NiCl}_{2} \bullet 6 \mathrm{H}_{2} \mathrm{O} .{ }^{10}$ All neutral complexes were isolated after purification as dark green waxy solids after drying. Full experimental details of the synthetic process and characterizations are presented in the Electronic Supplementary Information (ESI).

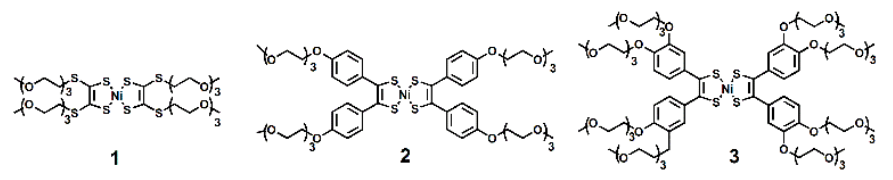

Figure 1. Chemical structures of the three pegylated nickel-bis(dithiolene) derivatives synthesized.

First of all, the solubility of the three complexes was evaluated in water. Complex 2 was found to be completely insoluble. Complex $\mathbf{1}$ is partially soluble and only a slight coloration of the solution was observed together with the presence of insoluble. On contrary, complex $\mathbf{3}$, carrying eight polyethylene glycol chains, is well soluble in water, giving rise to a marked green coloration (Figure 2 left). The solubility was determined to be above $10 \mathrm{mg} \cdot \mathrm{mL}^{-1}\left(5 \mathrm{mmol} \cdot \mathrm{L}^{-1}\right)$. Partitioning experiments in water/octanol mixtures have also been performed with complex $\mathbf{3}$. After phase separation, no trace of complex $\mathbf{3}$ has been detected 
by UV-visible-NIR measurements in the aqueous phase. These results highlight that complex $\mathbf{3}$ has strong lipophilic character which is in line with its relatively weak solubility in water.

The UV-visible-NIR absorption spectra of complex $\mathbf{3}$ in water display a strong absorption band centred at $936 \mathrm{~nm}$, extending from $700 \mathrm{~nm}$ up to $1200 \mathrm{~nm}$ with high extinction coefficients $\left(\varepsilon \approx 14200 \mathrm{M}^{-1} . \mathrm{cm}^{-1}\right)$ in the near-IR region, a characteristic of neutral Ni-bis(dithiolene) complexes (Figure 2 right). This lowenergy absorption band is attributed indeed to an electronic transition from the HOMO $(\mathrm{L} \pi)$ of $\mathrm{b}_{1 \mathrm{u}}$ symmetry to the LUMO $\left(\mathrm{L} \pi^{*}-\alpha \mathrm{d}_{\mathrm{xy}}\right)$ with a metallic character of $\mathrm{b}_{2 \mathrm{~g}}$ symmetry. ${ }^{11}$ Upon dilution, the absorbance perfectly follows the Beer-Lamber law, indicating the absence of intermolecular interactions below 500 $\mu \mathrm{g} \cdot \mathrm{mL}^{-1}$ in water (insert Figure 2). Spectroscopic data obtained in dichloromethane with complexes 1-3 are gathered in table $\mathrm{S} 1$. In $\mathrm{CH}_{2} \mathrm{Cl}_{2}$, the NIR-absorption maxima of complex 3 is slightly red-shifted to $948 \mathrm{~nm}$ but the extinction coefficient strongly increases $\left(\varepsilon \approx 36000 \mathrm{M}^{-1} \cdot \mathrm{cm}^{-1}\right)$.

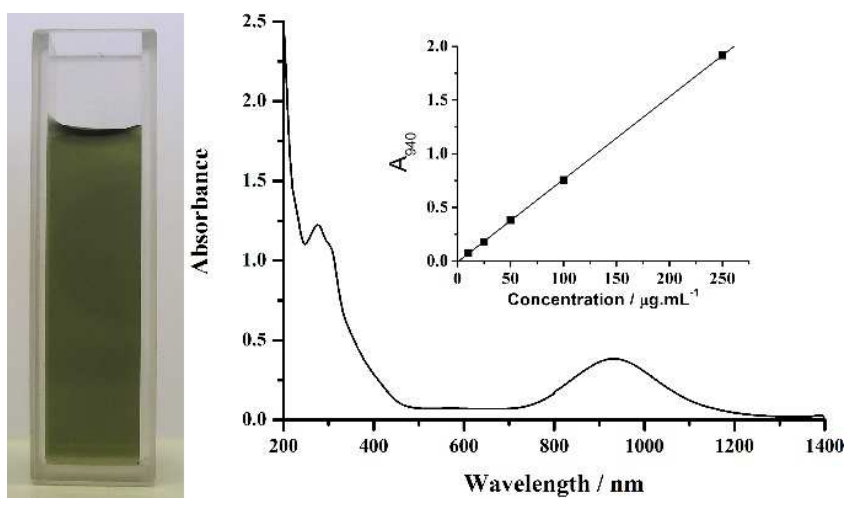

Figure 2. Picture of a dark-green solution of complex 3 in water $\left(\mathrm{c}=500 \mu \mathrm{g} \cdot \mathrm{mL}^{-1}\right)$ (left) and UV-vis-NIR spectra of complex 3 in water $\left(c=50 \mu \mathrm{g} \cdot \mathrm{mL}^{-1}\right.$ ) (right) (insert: evolution of the absorbance at $940 \mathrm{~nm}$ as a function of the concentration). 
A quantitative study of the photothermal performance of complex $\mathbf{3}$ in water was conducted. The temperature elevation of water solutions at different concentrations $\left(0-500 \mu \mathrm{g} \cdot \mathrm{mL}^{-1}\right)$ was measured under $940 \mathrm{~nm}$ laser irradiation with a power of $1 \mathrm{~W} \cdot \mathrm{cm}^{-2}$ for $10 \mathrm{~min}$ (Figure 3). An obvious concentrationdependent increase was observed after addition of complex $\mathbf{3}$ under laser irradiation. Below $25 \mu \mathrm{g} \cdot \mathrm{mL}^{-1}$, no noticeable photothermal effects have been detected. The temperature change $(\Delta \mathrm{T})$ drastically goes up with an increase of the complex concentration from 25 to $500 \mu \mathrm{g} \bullet \mathrm{mL}^{-1}$, and then reaches a maximum $(+20.2$ $\left.{ }^{\circ} \mathrm{C}\right)$. In contrast, the temperature increase in pure water was only $6.5^{\circ} \mathrm{C}$. As expected, the temperature also strongly increases with the irradiation power density. Temperature increase as high as $65{ }^{\circ} \mathrm{C}$ has been obtained with a power of $5 \mathrm{~W} \cdot \mathrm{cm}^{-2}$ for $10 \mathrm{~min}$ at $500 \mu \mathrm{g} \cdot \mathrm{L}^{-1}$ (Figure S1-S4).

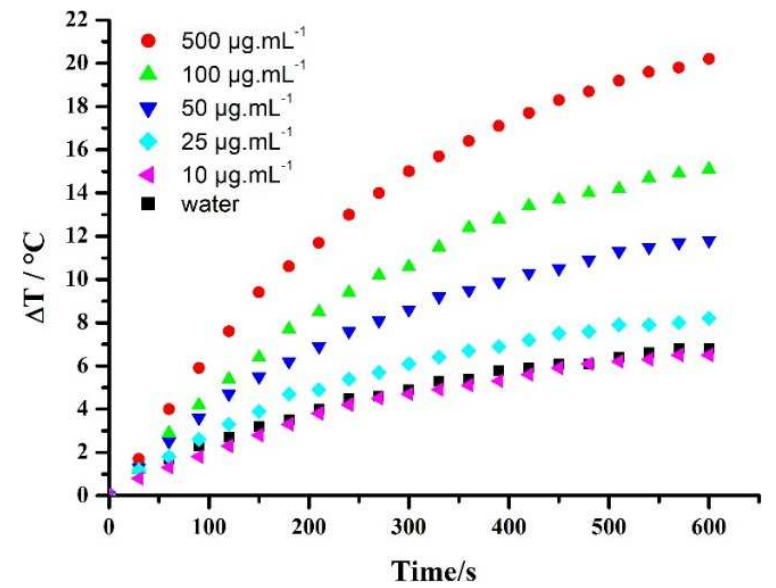

Figure 3. Temperature elevation of solutions of complex 3 in water at various concentrations $(0-500$ $\left.\mu \mathrm{g} \bullet \mathrm{mL}^{-1}\right)$ as a function of time $(0-600 \mathrm{~s})$ under irradiation with a $940 \mathrm{~nm}$ wavelength laser at a power of 1 W. $\mathrm{cm}^{-2}$.

The photothermal conversion efficiency $(\eta)$ was evaluated on solutions of complex 3 in water at 50, 100, $500 \mu \mathrm{g} . \mathrm{mL}^{-1}$ by monitoring the complete temperature profile under continuous irradiation at $940 \mathrm{~nm}$ laser 
with a power of $1 \mathrm{~W} . \mathrm{cm}^{-2}$ until $10 \mathrm{~min}$ and after turning off of the laser during $10 \mathrm{~min}$ (Figure S5-S7). The $\eta$ value was calculated according to the equation described by Roper and al. based on the energy balance of the system. ${ }^{12}$ The $\eta$ value determined for complex $\mathbf{3}$ in water is $\sim 12 \%$, which is close to the $\eta$ values measured with gold nanostructures (13-22\%) which are currently the object of great interest for photothermal therapy. ${ }^{4}$ NMR experiments and thin layer chromatography performed after NIR irradiation did not evidence any degradation of the complexes, confirming their remarkable photo-thermal stability, even after exposure to laser irradiation for a long time, in contrast to gold nanostructures. It should be noticed that this $\eta$ value is slightly lower than the one measured recently on cholesterol-substituted nickelbis(dithiolene) in decane $(\sim 19 \%),{ }^{8}$ highlighting the influence of the substitution pattern around the complex and the nature of the medium/solvent on the absorption and the conversion efficiency.

The good NIR-photothermal conversion efficiency of the octa-pegylated complex $\mathbf{3}$ in water prompted us to evaluate its potential as a PTT agent in vivo. MTT assays on human renal carcinoma cells (786-0) have shown that the viability remained above $80 \%$ after $24 \mathrm{~h}$ incubation for concentrations up to $100 \mu \mathrm{g} . \mathrm{mL}^{-1}$ $(60 \mu \mathrm{M})$ and more than $50 \%$ of the cells survive at $500 \mu \mathrm{g} \cdot \mathrm{mL}^{-1}$ (Figure 4 and S8). Earlier experiments have shown that cells can be killed in 4-6 min for temperatures above $50{ }^{\circ} \mathrm{C} .{ }^{4,13}$ In regard to the photothermal experiments performed in water (Figure S5-S7), concentrations of complex 3 above 100 $\mu \mathrm{g} \cdot \mathrm{mL}^{-1}$ under a power density of $2 \mathrm{~W} . \mathrm{cm}^{-2}$ or above $50 \mu \mathrm{g} \cdot \mathrm{mL}^{-1}$ under a power density of $5 \mathrm{~W} . \mathrm{cm}^{-2}$ should be used to reach $50{ }^{\circ} \mathrm{C}$ for irradiation performed at $25^{\circ} \mathrm{C}$. The cells were incubated with increasing amount of complex $3\left(50,100,150 \mu \mathrm{g} \cdot \mathrm{mL}^{-1}\right)$ for $24 \mathrm{~h}$ and then irradiated with a $940 \mathrm{~nm}$ NIR-laser for $10 \mathrm{~min}$ under power density of 2 or $5 \mathrm{~W} . \mathrm{cm}^{-2}$. Upon $5 \mathrm{~W} . \mathrm{cm}^{-2}$ power density laser irradiation, cell viability significantly decreased for concentrations of complex 3 above $100 \mu \mathrm{g} \cdot \mathrm{mL}^{-1}$ (Figure 4) and after 10 min, less than $20 \%$ of the cells remained alive after irradiation (70\% without irradiation). In contrast, cells without complex 3 incubation were not affected even after 10 min laser irradiation at the highest power density of 5 W.cm ${ }^{-2}$. 
Power density of $2 \mathrm{~W} . \mathrm{cm}^{-2}$ was found not to be sufficient to induce marked cell death in 10 min even at 150 $\mu \mathrm{g} \cdot \mathrm{mL}^{-1}$. After one day incubation with complex 3, the phase contrast observation of the cells was not markedly affected whereas after irradiation, the cells adopted a round shape, a sign of cell death (Figure S9). These preliminary in vivo results confirm our expectations that nickel-bis(dithiolene) complexes can indeed act as efficient photothermal agent as they are able to induce cell death under NIR irradiation.

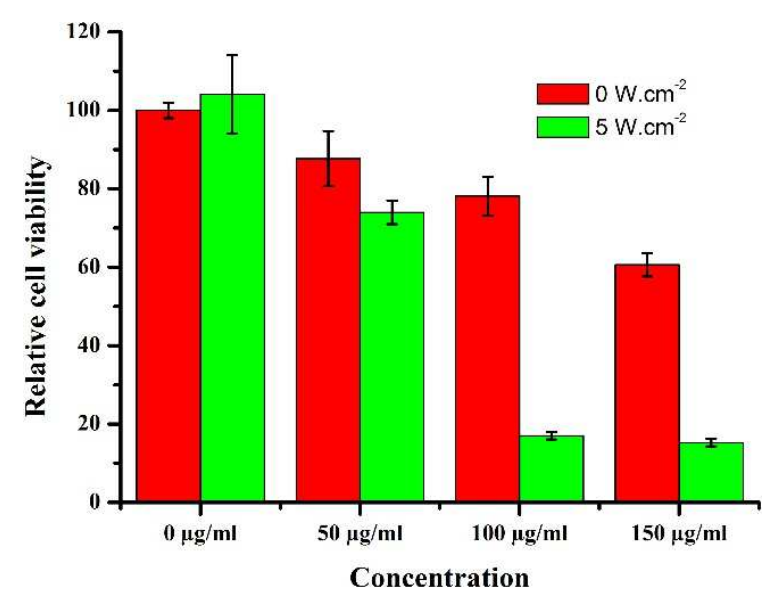

Figure 4. Relative Cell viability 786-0 human renal carcinoma cells treated with different concentrations of complex 3 without or with laser irradiation (940 nm, 5 W.cm $\left.{ }^{-2}, 10 \mathrm{~min}\right)$.

In summary, original water-soluble nickel-bis(dithiolene) complexes with good photothermal conversion in water and biocompatibility, were successfully prepared by grafting polyethylene glycol chains on the dithiolene complex core structure. Under NIR irradiation at $940 \mathrm{~nm}$-with a safe power density of $0.5-5$ W.cm ${ }^{-2}$, the temperature of aqueous solutions of complex $3\left(25-500 \mu \mathrm{g} . \mathrm{mL}^{-1}\right)$ can increase by $6.3-65.5^{\circ} \mathrm{C}$ in 10 min. Importantly, the in cellulo experiments have demonstrated that NIR-laser irradiation at concentrations around $100 \mu \mathrm{g} \cdot \mathrm{mL}^{-1}(60 \mu \mathrm{M})$ for 5 min can induced cell death. This class of metal complexes provides a new generation of molecular therapeutic agents for photothermal therapy. Proper functionalization of these complexes should improve their photothermal efficiency and their 
biocompatibility as well as their targeting abilities. Efforts along these lines are currently under progress in our laboratory.

This study was inspired by earlier discussions with U. T. Müller-Westerhoff in 2008 during a meeting in Philadelphia. ${ }^{14}$

\section{Notes and references}

1 - BIOSIT - Rennes, France.

$\dagger$ Electronic Supplementary Information (ESI) available: Experimental details, synthesis, Time evolution of the temperature of solution of complex 3 in water at various concentrations $\left(0-500 \mu \mathrm{g} \bullet \mathrm{mL}^{-}\right.$ $\left.{ }^{1}\right)$ as a function of time $(0-600 \mathrm{~s})$ under irradiation with a $940 \mathrm{~nm}$ wavelength laser at a power of 0.5 , 2 and $5 \mathrm{~W} . \mathrm{cm}^{-2}$, temperature profiles and time constants for heat transfer determined on solutions of complex 3 in water at 50, 100, $500 \mu \mathrm{g} \bullet \mathrm{mL}^{-1}$, Cell viability after $24 \mathrm{~h}$ incubation with various concentrations of complex 3 and images of the cells before and after irradiation in presence or not of complex 3. See DOI: 10.1039/c000000x/

1 a) E. I. Altinoglu and J. H. Adair, Wiley Interdiscip. Rev. Nanomed. Nanobiotechnol., 2010, 2 , 461; b) Q. Tian, M. Tang, Y. Sun, R. Zou, Z. Chen, M. Zhu, S. Yang, J. Wang, J. Wang and J. Hu, Adv. Mater., 2011, 23, 3542.

2 a) J. Yu, D. Javier, M. A. Yaseen, N. Nitin, R. Richards-Kortum, B. Anvari and M. S. Wong, J. Am. Chem. Soc., 2010, 132, 1929; b) J. Yang, J. Choi, D. Bang, E. Kim, E. K. Lim, H. Park, J. S. Suh, K. Lee, K. H. Yoo, E. K. Kim, Y. M. Huh and S. Haam, Angew. Chem. Int. Ed., 2011, 50, 441 . 
3 Z. M. Markovic, L. M. Harhaji-Trajkovic, B. M. Todorovic-Markovic, D. P. Kepic, K. M. Arsikin, S. P. Jovanovic, A. C. Pantovic, M. D. Dramicanin and V. S. Trajkovic, Biomaterials, $2011,32,1121$

4 D. Jaque, L. Martínez Maestro, B. del Rosal, P. Haro-Gonzalez, A. Benayas, J. L. Plaza, E. Martín Rodríguez and J. García Solé, nanoscale, 2014, 6, 9494

5 M. Zhou, R. Zhang, M. A. Huang, W. Lu, S. L. Song, M. P. Melancon, M. Tian, D. Liang and C. Li, J. Am. Chem. Soc. 2010, 132, 15351.

6 C. M. Hessel, V. . Pattani, M. Rasch, M. G. Panthani, B. Koo, J. W. Tunnell and B. A. Korgel, Nano Lett., 2011, 11, 2560.

7 S. Kawakami and Y. Kojima, Japan Kokai Tokkyo Koho, JP 04153086, A 19920526, 1992.

8 K. Mebrouk, S. Debnath, M. Fourmigue and F. Camerel, Langmuir, 2014, 30, 8592.

9 W. W. Yu, E. Chang, J. C. Falkner, J. Zhang, A. M. Al-Somali, C. M. Sayes, J. Johns, R. Drezek and V. L. Colvin, J. Am. Chem. Soc., 2007, 129, 2871.

10 R. Perochon, P. Davidson, S. Rouzière, F. Camerel, L. Piekara-Sady, T. Guizouarn and M. Fourmigué, J. Mater. Chem., 2011, 21, 1416.

11 M. L. Kirk, R. L. McNaughton and M. E. Helton, In Dithiolene Chemistry: Syntheses, Properties and Applications, Prog. Inorg. Chem., 2004, vol. 52, Ch. 3, pp 111.

12 D. K. Roper, W. Ahn and M. Hoepfner, J. Phys. Chem. C, 2007, 111, 3636.

13 R.W.Y. Habash, R. Bansal, D. Krewski and H.T. Alhafid, Crit. Rev. Biomed. Eng., 2006, 34, 459.

14 U. T. Müller-Westerhoff, Abstracts of papers of the ACS, 2008, 236, 330-INOR. 


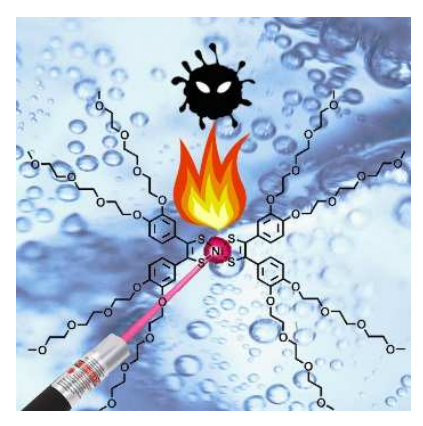

Pegylated nickel-bis(dithiolene) complexes can efficiently convert NIR light into heat in water to induce cells death. 
